\title{
$\mathrm{Pt}$ 금속마스크를 이용하여 제작한 나노패턴 $\mathrm{Si}(111)$ 기판위에 성장한 $\mathrm{GaN}$ 박막 특성
}

\author{
김종옥 · 임기영" \\ 전북대학교 반도체 화학공학부, 반도체 물성 연구소
}

\section{Characterization of GaN epitaxial layer grown on nano-patterned Si(111) substrate using Pt metal-mask}

\author{
Jong-Ock Kim and Kee-Young Lim $^{\dagger}$ \\ School of Semiconductor and Chemical Engineering, Semiconductor Physics Research Center, Chonbuk National \\ University, Jeonju-si 561-756, Korea
}

(2013년 6월 24일 접수: 2014년 7월 8일 수정: 2014년 9월18일 게재확정)

\begin{abstract}
초 록: 본 연구에서는 $\mathrm{Si}(111)$ 기판을 이용하여 고품질의 $\mathrm{GaN}$ 박막을 성장하기 위하여 다양한 패턴을 갖는 $\mathrm{Si}$ 기판을 제작하였다. $\mathrm{Si}(111)$ 기판위에 이온 스퍼터(ion-sputter)를 이용하여 Pt 박막을 증착한 후 열처리(thermal annealing)하여 $\mathrm{Pt}$ 금속 마스크를 형성하고 유도 결합 플라즈마 이온 식각(inductively coupled plasma-reactive ion etching, ICP-RIE) 공정을 통하여 기둥(pillar)형태의 나노 패턴된 $\mathrm{Si}(111)$ 기판을 제작하였고 리소그래피 공정을 통하여 마이크로 패턴된 $\mathrm{Si}(111)$ 기 판을 제작하였다. 일반적인 $\mathrm{Si}(111)$ 기판, 마이크로 패턴된 $\mathrm{Si}(111)$ 기판 및 나노 패턴된 $\mathrm{Si}(111)$ 기판위에 유기화학기상증 착(metal organic chemical vapor deposition, MOCVD) 방법으로 $\mathrm{GaN}$ 박막을 성장하여 표면 특성과 결정성 및 광학적 특 성을 분석하였다. 나노 패턴된 $\mathrm{Si}(111)$ 기판위에 성장한 $\mathrm{GaN}$ 박막은 일반적인 $\mathrm{Si}(111)$ 기판과 마이크로 패턴된 $\mathrm{Si}(111)$ 기 판위에 성장한 $\mathrm{GaN}$ 박막보다 표면의 균열과 거칠기가 개선되었다. 나노 패턴된 $\mathrm{Si}(111)$ 기판위에 성장한 $\mathrm{GaN}(002)$ 면과 (102)면에 x-선 회절(x-ray diffraction, XRD) 피크의 반폭치(full width at half maximum, FWHM)는 576 arcsec, 828 arcsec으로 다른 두 기판위에 성장한 $\mathrm{GaN}$ 박막 보다 가장 낮은 값을 보여 결정성이 향상되었음을 확인하였다. Photoluminescence(PL)의 반폭치는 나노 패턴된 $\mathrm{Si}(111)$ 기판위에 성장한 $\mathrm{GaN}$ 박막이 $46.5 \mathrm{meV}$ 으로 다른 기판위에 성장한 $\mathrm{GaN}$ 박막과 비교하여 광학적 특성이 향상되었음을 확인하였다.
\end{abstract}

\begin{abstract}
An attempt to grow high quality GaN on silicon substrate using metal organic chemical vapor deposition (MOCVD), herein GaN epitaxial layers were grown on various $\mathrm{Si}(111)$ substrates. Thin Platinum layer was deposited on $\mathrm{Si}(111)$ substrate using sputtering, followed by thermal annealing to form Pt nano-clusters which act as masking layer during dry-etched with inductively coupled plasma-reactive ion etching to generate nano-patterned $\mathrm{Si}$ (111) substrate. In addition, micro-patterned Si (111) substrate with circle shape was also fabricated by using conventional photo-lithography technique. GaN epitaxial layers were subsequently grown on micro-, nano-patterned and conventional $\mathrm{Si}$ (111) substrate under identical growth conditions for comparison. The GaN layer grown on nano-patterned $\mathrm{Si}$ (111) substrate shows the lowest crack density with mirror-like surface morphology. The FWHM values of XRD rocking curve measured from symmetry (002) and asymmetry (102) planes are 576 arcsec and 828 arcsec, respectively. To corroborate an enhancement of the growth quality, the FWHM value achieved from the photoluminescence spectra also shows the lowest value $(46.5 \mathrm{meV})$ as compare to other grown samples.
\end{abstract}

Keywords: GaN, MOCVD, Pt metal-mask, Si(111) substrate, nano-pattern

\section{1. 서 론}

육방정계 결정 구조를 갖는 $\mathrm{GaN}$ 는 직접천이형 밴드갭 을 갖는 반도체로써 광전소자와 전기소자 제작을 위한 재 료로 커다란 주목을 받고 있다. GaN는 열전도도(thermal conductivity)가 크고 융점이 높아 고온에서 안정하며, 큰 포화 전자 이동속도(saturated electron mobile velocity)를 가지는 전기적 특성과 내부식성, 내열성 등의 우수한 물 리, 화학적 특성을 가진 물질로 발광소자 및 고전압, 고 출력, 고주파 전기 소자로 이용될 수 있는 유망한 반도체

Corresponding author
E-mail: kylim $@$ ijbnu.ac.k

(C) 2014, The Korean Microelectronics and Packaging Society

This is an Open-Access article distributed under the terms of the Creative Commons Attribution Non-Commercial License(http://creativecommons.org/ licenses/by-nc/3.0) which permits unrestricted non-commercial use, distribution, and reproduction in any medium, provided the original work is properly cited. 
재료이다. ${ }^{1-5)}$ 특히 $\mathrm{GaN}$ 계 반도체를 기반으로 한 청색 및 백색 LED가 상용화 되면서 LED 시장은 매년 급속도로 팽창하고 있다. 이와 관련하여 칩의 대형화, 발광효율 개 선, 방열 패키지 기술의 개선을 위한 노력이 활발히 이루 어지고 있다. ${ }^{6-9)}$

$\mathrm{GaN}$ 계 박막은 주로 sapphire 기판이나 $\mathrm{SiC}$ 기판을 이 용하여 성장을 하지만 sapphire 기판은 전기적 절연체이 며 경도가 높아 소자 제작 시 어려움이 있고, $\mathrm{SiC}$ 기판은 높은 가격 때문에 대면적의 기판을 사용하기가 어렵다. 이러한 문제점들을 해결하기 위하여 낮은 가격, 대면적 웨이퍼의 효용성, 높은 열전도도 및 잘 발달된 공정 기술 을 응용 할 수 있는 $\mathrm{Si}$ 기판을 사용한 $\mathrm{GaN}$ 박막성장의 연 구가 수행되고 있다. ${ }^{10-13)}$ 그러나 $\mathrm{Si}$ 기판과 $\mathrm{GaN}$ 박막 사 이에는 열팽창 계수 차이와 매우 큰 격자 부정합으로 인 한 인장응력(tensile stress)이 유발되어 $\mathrm{GaN}$ 박막 표면의 균열(crack)을 발생시키고 박막내부에 매우 높은 전위 밀 도(dislocation density)를 형성시키기 때문에 반도체 소자 의 특성을 저하시켜 고효율의 소자를 구현하기 어렵다. 최근에 이와 같은 문제점을 보완하고자 다공성을 갖는 silicon 기판, 나노 패턴된 silicon-on-insulator (SOI), $\mathrm{Si}$ 나 노기둥(nano-pillar) 등을 이용하여 $\mathrm{GaN}$ 박막의 특성을 향 상시키는 연구가 활발히 수행되고 있다. ${ }^{14-16)}$

본 연구에서는 Pt 금속 마스크를 이용하여 기둥(pillar) 형태의 나노 패턴된 $\mathrm{Si}(111)$ 기판을 제작하여 MOCVD 방 법으로 $\mathrm{GaN}$ 박막을 성장하였다. 또한 광 리소그래피 공 정을 통하여 마이크로 패턴된 $\mathrm{Si}(111)$ 기판을 제작하고 패 턴이 없는 일반적인 $\mathrm{Si}(111)$ 기판과 마이크로 패턴된 $\mathrm{Si}(111)$ 기판위에 $\mathrm{GaN}$ 박막을 성장하여 나노 패턴된 $\mathrm{Si}(111)$ 기판위에 성장한 $\mathrm{GaN}$ 박막과 비교분석 하였다.

\section{2. 실험 방법}

본 연구에서는 $\mathrm{Si}(111)$ 기판 위에 이온 스퍼터로 약 $8 \mathrm{~nm}$ 두께로 증착한 $\mathrm{Pt}$ 금속막을 $940^{\circ} \mathrm{C}$ 에서 $60 \mathrm{~s}$ 동안 열처리를 하여 수십 nm 직경을 갖는 Pt cluster를 형성한 후, 이를 마 스크로 이용하여 유도 결합 플라즈마 반응 이온 식각 (inductively coupled plasma-reactive ion etching, ICP-RIE) 공정으로 원형 기둥 형태의 나노 패턴된 $\mathrm{Si}(111)$ 기판을 제작하였다. $\mathrm{Si}(111)$ 기판위에 마이크로 크기의 원형 기 둥 형태를 갖는 패턴은 일반적인 광 리소그래피(photolithography) 공정을 통하여 제작하였다. $\mathrm{GaN}$ 박막은 $\mathrm{Si}(111)$ 기판에 제작한 각각의 패턴이 $\mathrm{GaN}$ 박막의 성장 에 미치는 영향을 연구하기 위하여 AIN 완충층을 사용하 여 동일한 성장조건으로 $\mathrm{MOCVD}$ 반응로(reactor)에서 동 시에 성장하였다.

나노 패턴과 마이크로 패턴된 $\mathrm{Si}(111)$ 기판 그리고 일 반적인 $\mathrm{Si}(111)$ 기판은 성장 하기 전에 아세톤용액과 메탄 올용액으로 유기세척을 하였다. 그 후에 B.O.E(buffered oxide enchant)용액을 이용하여 $\mathrm{Si}(111)$ 기판표면에 존재하
는 자연 산화막을 제거한 다음, 끓는 IPA(isopropyl alcohol) 용액으로 기판의 수분을 제거하고 $\mathrm{N}_{2}$ 가스로 건조하였다.

유기세척 및 산화막이 제거된 각각의 $\mathrm{Si}(111)$ 기판은 $\mathrm{MOCVD}$ 장비를 이용하여 $\mathrm{AIN}$ 완충층을 $1050^{\circ} \mathrm{C}$ 에서 66 $\mathrm{mbar}$ 압력으로 $480 \mathrm{~s}$ 동안 $120 \mathrm{~nm}$ 두께로 성장한 다음 $\mathrm{GaN}$ 박막을 $1050^{\circ} \mathrm{C}$ 에서 $250 \mathrm{mbar}$ 압력으로 $3600 \mathrm{~s}$ 동안 $2 \mu \mathrm{m}$ 의 두께로 성장하였다. $\mathrm{AlN}$ 완충층 성장과 $\mathrm{GaN}$ 박 막 성장은 각각 TMAl (trimethylaluminium, $\left(\mathrm{CH}_{3}\right)_{3} \mathrm{Al}$ ), 암 모니아 $\left(\mathrm{NH}_{3}\right)$ 와 TMGa (trimethyl gallium, $\left.\left(\mathrm{CH}_{3}\right)_{3} \mathrm{Ga}\right)$, 암모 니아 $\left(\mathrm{NH}_{3}\right)$ 를 사용하여 성장하였다.

각각의 기판위에 성장된 $\mathrm{GaN}$ 박막의 특성 분석은 광학 현미경(optical microscopy, $\mathrm{OM}$ ), 주사형 전자현미경 (scanning electron microscopy, SEM), 원자 힘 현미경(atomic force microscopy, $\mathrm{AFM}$ ), X-선 회절(x-ray diffraction, $\mathrm{XRD}$ ) 그리고 광 루미네센스(photoluminesence, $\mathrm{PL}$ )측정을 이용 하여 박막의 결정성 및 광학적 특성을 분석하였다.

\section{3. 결과 및 고찰}

Fig. 1은 a) 나노 패턴된 $\mathrm{Si}$ (111)기판과 b) 마이크로 패 턴된 $\mathrm{Si}(111)$ 기판을 관찰한 $\mathrm{SEM}$ 이미지이다. 본 연구에 도입한 금속 마스크를 이용한 나노 패턴 제작은 열처리 를 이용한 자가 정렬을 유도하는 방식이기 때문에 낮은 정렬성을 갖는다. 본 연구에서는 나노 패턴의 균일도와 정렬성을 높일 수 있는 최적화 공정 실험을 통하여 Fig. 1 의 a)와 같이 $\mathrm{Si}(111)$ 기판위에 높은 정렬성을 갖는 기둥 형태의 나노 패턴을 형성하였다. 나노 패턴의 직경은 약 $40 \sim 60 \mathrm{~nm}$, 높이 약 120 140 nm 그리고 패턴의 분포 밀도 는 약 $5 \times 10^{10} \mathrm{~cm}^{-2}$ 로 확인되었다. Fig. $1 \mathrm{~b}$ )의 $\mathrm{Si}(111)$ 기판 위에 형성된 마이크로 패턴은 원형 기둥형태의 패턴이 형
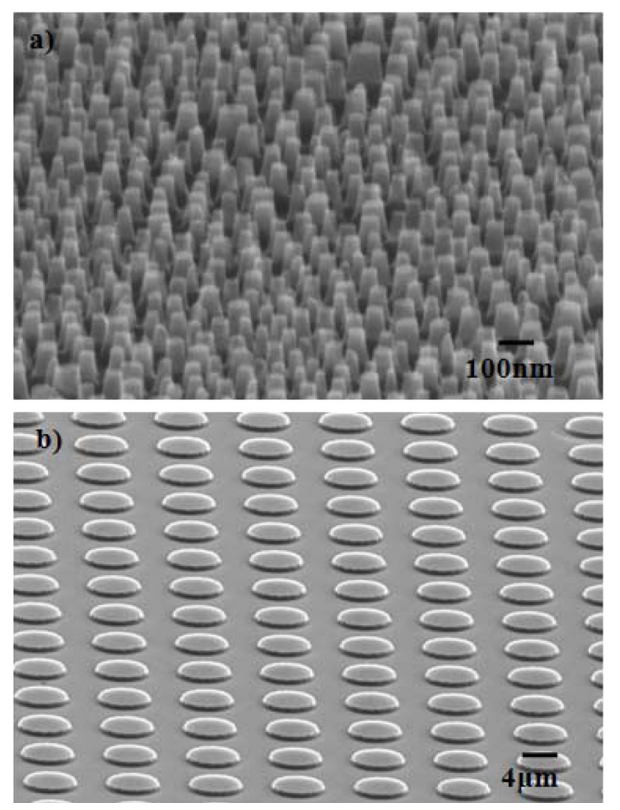

Fig. 1. SEM images of a) nano-patterned $\mathrm{Si}(111)$ substrate and $b$ ) micro-patterned $\mathrm{Si}(111)$ substrate. 


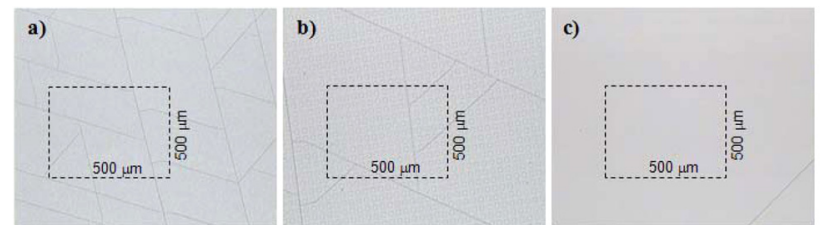

Fig. 2. OM images of the crack density in GaN epitaxial layers grown on a) conventional $\mathrm{Si}(111)$ substrate, b) micropatterned $\mathrm{Si}(111)$ substrate and c) nano-patterned $\mathrm{Si}(111)$ substrate.

성되었고 패턴의 직경은 $6 \mu \mathrm{m}$, 패턴사이의 간격은 $3 \mu \mathrm{m}$ 그리고 높이는 약 $450 \mathrm{~nm}$ 로 확인되었다.

Fig. 2 a)는 일반적인 $\mathrm{Si}(111)$ 기판위에 성장한 $\mathrm{GaN}$ 박 막, Fig. 2 b)는 마이크로 패턴된 $\mathrm{Si}(111)$ 기판위에 성장한 $\mathrm{GaN}$ 박막 그리고 Fig. 2 c)는 나노 패턴된 $\mathrm{Si}(111)$ 기판위 에 성장한 $\mathrm{GaN}$ 박막의 광학 현미경 $(\mathrm{OM})$ 이미지이다. 각 각의 $\mathrm{GaN}$ 박막은 $\mathrm{AlN}$ 완충층을 이용하여 $2 \mu \mathrm{m}$ 두께로 성장하였으며 경면과 같은(mirror-like) 표면을 보이고 있 으나 $\mathrm{GaN}$ 박막 표면에 crack이 발생하였다. 나노 패턴된 $\mathrm{Si}(111)$ 기판위에 성장한 $\mathrm{GaN}$ 박막이 일반적인 $\mathrm{Si}(111)$ 기 판과 마이크로 패턴된 $\mathrm{Si}(111)$ 기판위에 성장한 $\mathrm{GaN}$ 박 막보다 crack density가 감소됨을 확인하였다. $\mathrm{Si}$ 기판위 에 $\mathrm{GaN}$ 박막을 성장할 때 $\mathrm{GaN}$ 박막의 crack은 박막 성 장 중에 기판과 박막사이의 열팽창 계수 차이와 격자 불 일치로 인한 응력으로 발생한다. ${ }^{17)}$ 나노 패턴이 형성된 $\mathrm{Si}(111)$ 기판위에 성장한 $\mathrm{GaN}$ 박막의 crack density가 감 소된 것으로 미루어 볼 때 $\mathrm{Si}(111)$ 기판과 $\mathrm{GaN}$ 박막사이 의 응력이 감소되었음을 알 수 있다.

$\mathrm{GaN}$ 박막의 구조적 특성을 자세히 알아보기 위해 Fig. 3 에 보이는 바와 같이 각각의 $\mathrm{GaN}$ 박막의 표면과 단면을 전자현미경(SEM)으로 관찰하였다. Fig. 3 a)는 일반적인 $\mathrm{Si}(111)$ 기판위에 성장한 $\mathrm{GaN}$ 박막, Fig. 3 b)는 마이크로 패턴된 $\mathrm{Si}(111)$ 기판위에 성장한 $\mathrm{GaN}$ 박막 그리고 Fig.3 c)는 나노 패턴된 $\mathrm{Si}(111)$ 기판위에 성장한 $\mathrm{GaN}$ 박막의 표면과 단면 SEM 이미지이다. SEM 단면 이미지를 통하 여 각각의 $\mathrm{Si}(111)$ 기판에서 $120 \mathrm{~nm}$ 를 갖는 $\mathrm{AlN}$ 완충층
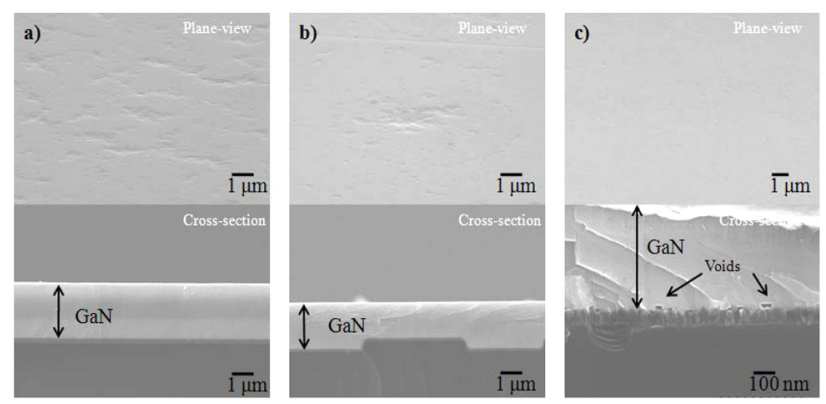

Fig. 3. SEM plane-view and cross-sectional images of the GaN epitaxial layers grown on a) conventional $\mathrm{Si}(111)$ substrate, b) micro-patterned $\mathrm{Si}(111)$ substrate and c) nano-patterned $\mathrm{Si}(111)$ substrate.
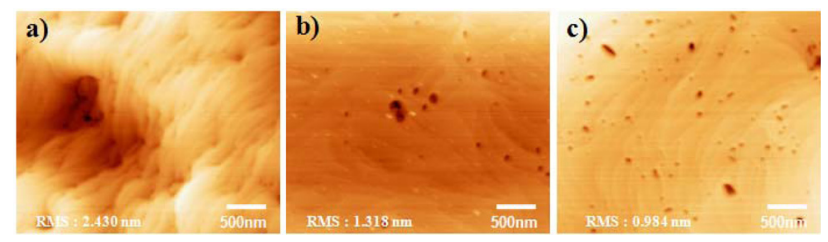

Fig. 4. AFM images of the surface morphology of the GaN epitaxial layers grown on a) conventional $\mathrm{Si}(111)$ substrate, b) micro-patterned $\mathrm{Si}(111)$ substrate and c) nano-patterned $\mathrm{Si}(111)$ substrate.

과 $2 \mu \mathrm{m}$ 두께의 $\mathrm{GaN}$ 박막이 성장됨을 확인하였고 $\mathrm{SEM}$ 표면 이미지에서 나노 패턴된 $\mathrm{Si}(111)$ 기판위에 성장한 $\mathrm{GaN}$ 박막은 일반적인 $\mathrm{Si}(111)$ 기판과 마이크로 패턴된 $\mathrm{Si}(111)$ 기판위에 성장한 $\mathrm{GaN}$ 박막보다 평탄한(smooth) 표면으로 성장되었음을 확인되었다. 이것은 Fig. 4의 $\mathrm{AFM}$ 으로 측정한 RMS(root mean square) 표면 거칠기 값 으로 확인 할 수 있다. 각각의 $\mathrm{Si}(111)$ 기판위에 성장된 $\mathrm{GaN}$ 박막의 RMS 거칠기 값은 a) $2.430 \mathrm{~nm}, \mathrm{~b}) 1.318 \mathrm{~nm}$ 그리고 c) $0.984 \mathrm{~nm}$ 로 나노 패턴된 $\mathrm{Si}(111)$ 기판위에 성장 한 $\mathrm{GaN}$ 박막이 다른 두 기판에서 성장한 $\mathrm{GaN}$ 박막보다 표면 거칠기가 감소하였다.

본 연구와 같이 기둥형태를 갖는 나노 패턴위에 $\mathrm{GaN}$ 박 막을 성장할 경우에는 수평성장(epitaxial lateral overgrowth, $\mathrm{ELOG}$ ) 메카니즘에 의해 나노 패턴과 $\mathrm{GaN}$ 박막계면에서 void 영역이 발생한다. 이 void 영역의 영향으로 인하여 통 과전위(threading dislocation)가 감소되어 양질의 $\mathrm{GaN}$ 박막 을 성장 할 수 있다고 보고되었다. ${ }^{18-19)} \mathrm{Fig} .3 \mathrm{c}$ )의 SEM 단 면이미지에서도 나노 패턴과 $\mathrm{GaN}$ 박막 계면에서 void 영 역이 형성됨을 확인하였고, 이러한 void 영역의 효과로 박막 내 통과전위가 감소되어 다른 기판위에 성장한 $\mathrm{GaN}$ 박막보다 양질의 $\mathrm{GaN}$ 박막이 성장된 것으로 판단된다.

Fig. 5는 성장된 $\mathrm{GaN}$ 박막의 결정성을 확인하기 위해 고 분해능 XRD 측정으로 $\mathrm{GaN}$ 박막의 (002)면과 (102)면 의 회절 피크를 측정하였다. (002)면의 회절 피크 측정은

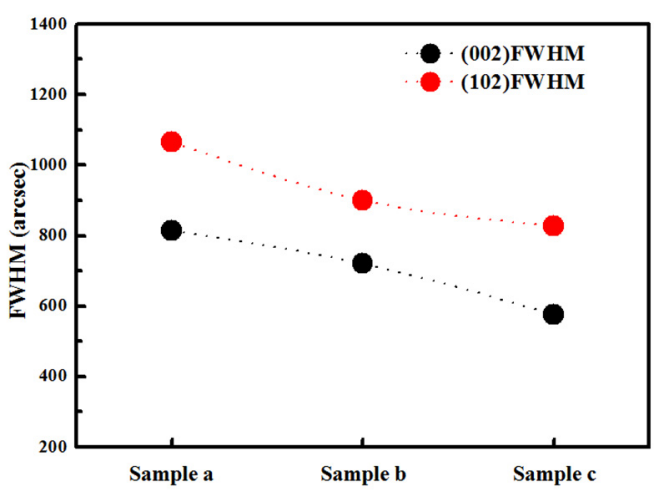

Fig. 5. FWHM of the $\mathrm{XRD}(002)$ and (102) diffraction peaks of $\mathrm{GaN}$ epitaxial layers grown on conventional $\mathrm{Si}(111)$ substrate (sample a), micro-patterned Si(111) substrate (sample b) and nano-patterned $\mathrm{Si}(111)$ substrate(sample c). 


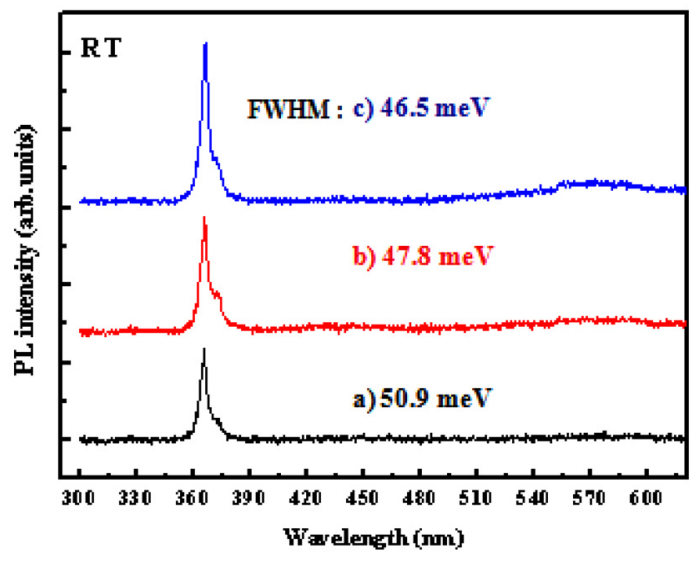

Fig. 6. PL spectrum of GaN epitaxial layers grown on a) conventional $\mathrm{Si}(111)$ substrate, b) micro-patterned $\mathrm{Si}(111)$ substrate and c) nano-patterned $\mathrm{Si}(111)$ substrate.

박막이 c축 방향으로의 변형으로 나선전위(screw dislocation)형성을 확인 할 수 있다. 섬유아연석형(wurtzite)구조 를 갖는 $\mathrm{GaN}$ 박막의 경우, 불합치 칼날전위(misfit edge dislocation)가 형성된다는 보고가 있어 ${ }^{20)} \mathrm{c}$ 축과 $\mathrm{a}$ 축의 모 든 전위를 알아보기 위해서는 (102)면의 회절 피크를 측 정하여 분석하는 것이 효과적이다. Fig. 5 의 sample a의 결과값은 일반적인 $\mathrm{Si}(111)$ 기판위에 성장한 $\mathrm{GaN}$ 박막의 (002)면과 (102)면의 XRD 반폭치(FWHM)로 각각 814 $\operatorname{arcsec}, 1,066 \operatorname{arcsec}$ 를 나타내었고 Fig. 5 sample b는 마 이크로 패턴된 $\mathrm{Si}(111)$ 기판위에 성장한 $\mathrm{GaN}$ 박막으로 (002)면과 (102)면의 FWHM는 각각 $720 \mathrm{arcsec}, 900$ $\operatorname{arcsec}$ 를 나타내었다. 또한, Fig. 5 sample c 의 나노 패턴 된 $\mathrm{Si}(111)$ 기판위에 성장한 $\mathrm{GaN}$ 박막의 (002)면과 (102) 면의 XRD FWHM는 각각 $576 \mathrm{arcsec}, 828 \mathrm{arcsec}$ 로 다른 두 $\mathrm{Si}(111)$ 기판위에 성장한 $\mathrm{GaN}$ 박막과 비교하여 가장 낮은 값을 나타내었다. 이는 나노 패턴된 $\mathrm{Si}(111)$ 기판위 에 성장한 $\mathrm{GaN}$ 박막은 $\mathrm{c}$ 축 변형과 $\mathrm{a}$ 축 변형이 다른 두 $\mathrm{Si}(111)$ 기판에서 성장한 $\mathrm{GaN}$ 박막보다 적게 변형된 것 을 알 수 있으며 상대적으로 박막내의 통과전위가 감소 되었음을 나타낸다.

$\mathrm{PL}$ 측정을 통하여 각각의 $\mathrm{Si}(111)$ 기판위에 성장한 $\mathrm{GaN}$ 박막의 광학적 특성을 분석하였다. Fig. 6 의 a)는 일 반적인 $\mathrm{Si}(111)$ 기판, b)는 마이크로 패턴된 $\mathrm{Si}(111)$ 기판 그리고 $\mathrm{c})$ 는 나노 패턴된 $\mathrm{Si}(111)$ 기판위에 성장한 $\mathrm{GaN}$ 박막을 나타낸 $\mathrm{PL}$ 스펙트럼이다. 상온에서 측정된 $\mathrm{PL}$ 스 펙트럼의 결과를 통하여 각각의 기판에서 성장한 $\mathrm{GaN}$ 박 막 모두 약 $365 \mathrm{~nm}(3.39 \mathrm{eV})$ 파장영역에서 밴드 가장자 리 광방출 (band edge emission)에 의한 주요 피크가 관측 되었으며 일반적인 $\mathrm{Si}(111)$ 기판에 성장한 $\mathrm{GaN}$ 박막은 $365.37 \mathrm{~nm}$, 마이크로 패턴된 $\mathrm{Si}(111)$ 기판에 성장한 $\mathrm{GaN}$ 박막은 $365.58 \mathrm{~nm}$ 그리고 나노 패턴된 $\mathrm{Si}(111)$ 기판에 성 장한 $\mathrm{GaN}$ 박막은 $366.02 \mathrm{~nm}$ 값을 나타내었다. 또한, 모든 sample들에서 빈자리(vacancy) 및 전위(dislocation) 등 여러
결함들과 관련된 옐로우 루미네센스(yellow luminescence) 는 발견되지 않았다. 보고되어진 바에 따르면 사파이어 기 판위에 성장한 $\mathrm{GaN}$ 박막의 $\mathrm{PL}$ 주요 피크는 약 361.09 $363.09 \mathrm{~nm}$ 에서 관측 된다. ${ }^{21)}$ 본 연구에서는 이 파장대역 에서 조금씩 적색 이동(red-shift)된 주요 피크들이 확인되 었다. 이는 $\mathrm{Si}$ 기판과 $\mathrm{GaN}$ 박막사이의 열팽창 계수와 격 자 상수 차이에 의해 $\mathrm{GaN}$ 박막에서 보이는 PL 피크 변 이이며 이러한 현상은 $\mathrm{GaN}$ 박막에 작용하는 응력의 변 화에 의한 것으로 생각된다.

일반적인 $\mathrm{Si}(111)$ 기판과 마이크로 패턴된 $\mathrm{Si}(111)$ 기판 그리고 나노 패턴된 $\mathrm{Si}(111)$ 기판위에 성장한 $\mathrm{GaN}$ 박막 의 PL FWHM는 파장(wavelength)을 에너지 준위 $(\mathrm{eV})$ 로 환산 하였을 때 각각 $50.9 \mathrm{meV}, 47.8 \mathrm{meV}, 46.5 \mathrm{meV}$ 으로 나노 패턴된 $\mathrm{Si}(111)$ 기판위에 성장한 $\mathrm{GaN}$ 박막의 반폭 치가 가장 낮았고 피크 강도는 가장 높은 값을 나타내었 다. 이는 다른 두 $\mathrm{Si}(111)$ 기판위에 성장한 $\mathrm{GaN}$ 박막보다 나노 패턴된 $\mathrm{Si}(111)$ 기판위에 성장한 $\mathrm{GaN}$ 박막이 박막 내의 통과전위를 더욱 감소시켜 비방사 재결합(nonradiative recombination) 센터작용을 줄임으로써 광학적 특성이 향상된 것으로 생각된다. ${ }^{22}$

\section{4. 결 론}

본 연구에서는 $\mathrm{Si}(111)$ 기판위에 $\mathrm{Pt}$ 금속막을 증착하여 열처리를 한 후 ICP-RIE 공정으로 $\mathrm{Si}(111)$ 기판위에 기둥 형태의 나노 패턴을 제작하였고, $\mathrm{Si}(111)$ 기판위에 마이 크로 패턴은 일반적인 photo-lithography 방법을 이용하여 제작하였다. 각각의 패턴된 $\mathrm{Si}(111)$ 기판 위에 $\mathrm{MOCVD}$ 방법으로 $\mathrm{GaN}$ 박막을 성장하여 기판에 형성된 패턴이 $\mathrm{GaN}$ 박막에 미치는 영향을 비교분석하였다. 일반적인 $\mathrm{Si}(111)$ 기판과 마이크로 패턴된 $\mathrm{Si}(111)$ 기판 그리고 나 노 패턴된 $\mathrm{Si}(111)$ 기판위에 성장한 $\mathrm{GaN}$ 박막을 $\mathrm{OM}$ 과 $\mathrm{SEM}$ 관찰을 통하여 비교 분석한 결과, 나노 패턴된 $\mathrm{Si}(111)$ 기판위에 성장한 $\mathrm{GaN}$ 박막이 일 반적인 $\mathrm{Si}(111)$ 기 판과 마이크로 패턴된 $\mathrm{Si}(111)$ 기판위에 성장한 $\mathrm{GaN}$ 박 막보다 crack density가 감소되었고 평탄한 표면을 갖는 $\mathrm{GaN}$ 박막이 성장됨을 알 수 있었다. 또한 $\mathrm{AFM}$ 측정을 통 하여 나노 패턴된 $\mathrm{Si}(111)$ 기판위에 성장한 $\mathrm{GaN}$ 박막이 $0.984 \mathrm{~nm}$ 의 RMS 값을 나타내어 양질의 박막이 성장되었 음을 확인하였다. 나노 패턴된 $\mathrm{Si}(111)$ 기판위에 성장된 $\mathrm{GaN}$ 박막의 (002)면과 (102)면의 XRD FWHM는 다른 $\mathrm{Si}(111)$ 기판위에 성장한 $\mathrm{GaN}$ 박막보다 상대적으로 낮은 값인 $576 \mathrm{arcsec}, 828 \mathrm{arcsec}$ 으로 결정성이 향상됨을 알 수 있었다. PL 특성 분석을 통하여 나노 패턴된 $\mathrm{Si}(111)$ 기판위에 형성된 $\mathrm{GaN}$ 박막은 주요 피크가 $366.02 \mathrm{~nm}$ 에 서 관측되었고 $46.5 \mathrm{meV}$ 를 갖는 $\mathrm{FWHM}$ 값으로 일반적 인 $\mathrm{Si}(111)$ 기판과 마이크로 패턴된 $\mathrm{Si}(111)$ 기판위에 성 장한 $\mathrm{GaN}$ 박막보다 광학적 특성이 향상됨을 보였다. 이 결과들을 토대로 $\mathrm{Si}(111)$ 기판위에 나노 패턴을 이용하여 
성장한 $\mathrm{GaN}$ 박막은 기판과 박막의 열팽창계수와 격자불 일치로 인한 $\mathrm{GaN}$ 박막의 균열과 통과전위 등을 감소시 킬 뿐만 아니라 발광소자 및 전기소자의 특성향상에 크 게 기여할 것으로 기대된다.

\section{감사의 글}

본 연구는 2013년도 정부(교육부)의 재원으로 한국연 구재단의 지원을 받아 수행된 기초연구사업(No. 20090094031, No.2013-013150)으로 이에 감사드립니다.

\section{Refernces}

1. S. Strite and H. Morkoc, "GaN, AIN, and InN: A review", J. Vac. Sci. Technol. B. 10(4), 1237 (1992).

2. T. Tetsuya, T. Hideo, S. Shigetoshi and S. Hiromitsu, "Optcial Properties of Strained AlGaN and GaInN on GaN", Jpn. J. Appl. Phys. 36(2B), L177 (1997).

3. S. Nakamura, M. Senoh, S. Nagahama, N. Iwasa, T. Yamada, T. Matsushita H. Kiyoku and Y. Sugimoto, "InGaN-Based Multi-Quant $\mu \mathrm{m}-$ Well-Structure Laser Diodes”, Jpn. J. Appl. Phys. 35(1B), L74 (1996).

4. R. Chu, Z. Chen and Y. Pei, "MOCVD-Grown AlGaN Buffer GaN HEMTs With V-Gates for Microwave Power Applications", IEEE Trans. Electron Devices. 30(9), 910 (2009).

5. S. C. Jain, M. Willander, J. Narayan and R. Van Overstraeten, "III-nitrides: Growth, characterization, and properties", J. Appl. Phys. 87(3), 965 (2000).

6. J. Park, M. W. Shin and C. C. Lee, "Measurement of temperature profiles on visible light-emitting diodes by use of a nematic liquid crystal and an infrared laser", Optics Lett. 29(22), 2657 (2004).

7. L. Kim and M. W. Shin, "Thermal Resistance Measurement of LED Package with Multichips", IEEE Trans. Compon Packag Tech. 30(4), 632 (2007).

8. H. J. Kang, H. Y. Song and M. Y. Jeong, "Design of Structure for High-Efficiency LEDs On Patterned Sapphire SubStrate", J. Microelectron. Packag. Soc., 18(4), 91 (2011).

9. B. K. Yu, M. Y. Kim and T. S. Oh, "Anisotropic Wet-Etching Process Of $\mathrm{Si}$ substrate for Formation of Thermal Vias in High-Power LED Packages", J. Microelectron. Packag. Soc., 19(4), 51 (2012).
10. A. Dadgar, M. Poschenrieder, J. Blasing, O. Contreras, F. Bertram, T. Riemann, A. Reiher, M. Kunze, I. Daumiller, A. Krtschil, A. Diez, A. Kaluza, A. Modlich, M. Kamp, J. Christen, F. A. Ponce, E. Kohn and A. Krost, "MOVPE growth of GaN on $\mathrm{Si}(111)$ substrates", J. Cryst. Growth. 248, 556 (2003).

11. X. Zhang, S. J. Chua, P. Li, K. B. Chong and Z. C. Feng, "Enhanced optical emission from GaN films grown on a silicon substrate", Appl. Phys. Lett. 74(14), 1984 (1999).

12. A. Dadgar, J. Blaing, A. Diez and A. Krost, "Crack-Free, Highly Conducting GaN layers on Si Substrates by Ge Doping”, Appl. Phys. Ex., 4, 011001 (2011).

13. A. Reiher, J. Bläsing, A. Dadgar, A. Diez and A. Krost, "Efficient stress relief in GaN heteroepitaxy on $\mathrm{Si}(111)$ using lowtemperature AIN interlayers", J. Cryst. Growth. 248, 563 (2003).

14. H. Ishikawa, K. Shimanaka, M. Azfar bin, M Amir, Y. Hara and M. Nakanishi, "Improved MOCVD growth of GaN on Sion-porous-silicon substrates", Phys. Stat. Sol(C). 7(7), 2049 (2010).

15. L. S. Wang, S. J. Chua, S. Tripathy, K. Y. Zang, B. Z. Wang and J. H. Teng, "Nanopatterning and selective area epitaxy of GaN on Si substrate", Proc. of SPIE., 6894, 68940 (2008).

16. C. C. Huang, S. J. Chang, C. H. Kuo, C. H. Wu, C. H. Ko, H. Wann, Y. C. Cheng and W. J. Lin, "Single Crystalline GaN Epitaxial Layer Prepared on Nano-patterned Si(001) Substrate", J. Electrochem. Soc. 158(6), H626 (2011)

17. S. Pal and C. Jacon, "Silicon-a new substrate for $\mathrm{GaN}$ growth", Bull. Mater. Sci. 27(6), 501 (2004).

18. S. D. Hersee, X. Y. Sun, X. Wang and M. N. Fairchild, "Nanoheteroepitaxial growth of GaN on Si nanopillar arrays", Appl. Phys. Lett., 97, 124308 (2005).

19. Y. Li, S. You, M. Zhu, L. Zhao and W. Hou, "Defect-reduced green $\mathrm{GaInN} / \mathrm{GaN}$ light-emitting diode on nanopatterned sapphire", Appl. Phys. Lett., 98, 151102 (2011).

20. J. Elsner and R. Jones, "Theory of Threading Edge and Screw Dislocation in GaN", Phys. Rev. Lett., 79(19), 3672 (1997).

21. H. Ishikawa, G. Y. Zhao, N. Nakada, T. Egawa, T. Jimbo and M. $\mu$ meno, "GaN on Si substrate with AlGaN/AIN Intermediate Layer”, Jpn. J. Appl. Phys., 38(5A), L492 (1999).

22. Josh Abell and T. D. Moustakas, "The role of dislocations as nonradiative recombination center in InGaN quantum wells", Appl. Phys. Lett., 92, 091901 (2008). 